\title{
MANAJEMEN PENGELOLAAN LIMBAH RUMAH SAKIT UMUM DAERAH POLEWALI DI MASA PANDEMI COVID-19
}

\author{
Sukmawati ${ }^{*}$, Maarifah Dahlan \\ Fakultas Kesehatan Masyarakat Universitas Al Asyariah Mandar, Polewali, Indonesia \\ email: cummasyarif@gmail.com
}

\begin{abstract}
Abstrak
Bencana pandemik Covid-19 telah mengakibatkan ribuan orang meninggal dan dirawat di rumah sakit sehingga dalam penanganan pasien Covid-19 membutuhkan perlengkapan medis yang lebih banyak daripada kondisi normal. Limbah B3 Medis yang dihasilkan RSUD Polewali sebangak $12.000 \mathrm{~kg}$ pada tahun 2020. Tujuan menelitian untuk mengetahui manajemen pengelolaan limbah selama pandemik Covid-19 di RSUD Polewali. Metode yang digunakan desain penelitian kualitatif dengan pendekatan studi kasus. Informan penelitian yaitu Kepala Rumah Sakit, Penanggung Jawab Kesehatan Lingkungan, Petugas incinerator, cleaning service, Kepala Ruangan Instalasi dan Bagian Perencanaan. Penelitian di RSUD Polewali menunjukkan bahwa manajemen pengelolaan limbah sudah melakukan identifikasi, pemisahan, labeling, pengangkutan, penyimpanan hingga pembuangan/pemusnahan serta menggunakan pihak ketiga untuk limbah dalam proses pembuangan akhir sesuai dengan Pedoman Pengelolaan Limbah rumah Sakit Rujukan, Rumah Sakit Darurat dan Puskesmas yang menangani Pasien Covid-19 Kementrian Kesehatan Republik Indonesia tahun 2020. Kesimpulan dari penelitian ini manajemen Pengelolaan Limbah Padat Domestik, Limbah Cair, dan Limbah B3 Medis Padat Rumah Sakit Umum Daerah Polewali menunjukkan dalam pengelolaan sudah memiliki SOP dengan merujuk pada Pedoman Pengelolaan Limbah rumah Sakit Rujukan.
\end{abstract}

Kata kunci : beban kerja psikologis, NASA-TLX, perawat covid-19

\begin{abstract}
The Covid-19 pandemic disaster has resulted in thousands of people dying and being treated in hospitals, so handling Covid-19 patients requires more medical equipment than normal conditions. Medical B3 waste generated by RSUD Polewali is 12,000 kg in 2020. The purpose of this research is to determine the management of waste management during the covid-19 pandemic at RSUD Polewali. The method used is a qualitative research design with a case study approach. Research informants are the Head of the Hospital, Person in Charge of Environmental Health, Incinerator Officer, cleaning service, Head of Installation Room and Planning Section. Research at Polewali Hospital shows that waste management management has identified, separated, labeled, transported, stored and disposed of/destroyed and used third parties for solid medical B3 waste in the final disposal process in accordance with the Waste Management Guidelines for Referral Hospitals, Emergency Hospitals and Hospitals. Health Center that handles Covid-19 Patients of the Ministry of Health of the Republic of Indonesia in 2020. The conclusion of this study is that the management of Domestic Solid Waste Management, Liquid Waste, and Medical B3 Solid Waste at the Polewali Regional General Hospital shows that the management already has an SOP by referring to the Referral Hospital Waste Management Guidelines.
\end{abstract}

Keywords : waste management, hospital, covid-19

\section{PENDAHULUAN}

Covid-19 telah dinyatakan sebagai pandemi dunia oleh WHO (World Health Organization, 2021). Pandemik Covid-19 yang melanda hampir seluruh negara di dunia termasuk Indonesia telah berdampak pada berbagai sektor kesehatan maupun nonkesehatan dengan mengeluarkan berbagai 
kebjiakan dalam rangka memutus mata rantai penularan dan mengurangi dampak (Direktor Pelayanan Kesehatan Primer, 2020). Dilaporkan kasus positif virus corona di Indonesia telah menjangkit sekitar 381.910 orang dengan kematian 13.077 orang dan diprediksi angka ini terus bertambah. (Satuan Tugas Penangan Covid-19, 2020).

Provinsi Sulawesi Barat pertama kali terjangkit virus corona pada bulan Mei tahun 2020 dan telah ditemukan 971 kasus positif dengan kematian sebanyak 12 orang. Kabupaten Polewali Mandar merupakan salah satu Kabupaten yang ada di Sulawesi Barat dengan kasus positif Covid-19 tertinggi dengan jumlah kasus 6.469 orang dan jumlah kematian 132 orang (Dinas Kesehatan Sulawesi Barat, 2020).

Berdasarkan Keputusan Presiden RI No. 12 Tahun 2020 tentang penetapan bencana non alam penyebaran Covid-19 sebagai bencana nasional, dengan diberlakukannya keputusan presiden tersebut, maka seluruh sumberdaya dikerahkan pada penanganan korban di rumah sakit khusus penangan Covid-19. Rumah Sakit Umum Daerah Polewali sebagai rumah sakit rujukan di Kabupaten Polewali Mandar yang mengakibatkan semua individu yang berada di rumah sakit berisiko untuk terpapar limbah Bahan Berbahaya dan Beracun (B3).

Salah satu persoalan di tengah pandemi adalah limbah penangan virus Corona. Limbah ini merupakan limbah medis tergolong sampah bahan berbahaya dan beracun. Adapun limbah tersebut berupa masker, sarung tangan, perban bekas, tisu bekas, alat suntik bekas, set infus bekas, bekas alat pelindung diri (APD), hingga sisa makanan pasien. Menteri LHK menyebutkan volume medis infeksius di seluruh Indonesia hingga 8 Juni 2020 mencapai lebih dari 1.100 ton (Kwan, 2020) dengan timbulan medis 14,3 kg/hari (Astuti, 2020).

Akibat pengelolaan yang kurang hati-hati, petugas yang berada di tempat perawatan kesehatan yang menghasilkan limbah maupun yang berada di luar sumber namun bertugas untuk menangani limbah tersebut berisiko (Rudraswamy, 2014). Surat edaran yang dikeluarkan oleh Kemenkes dijelaskan cara mengelola limbah mulai dari pengendalian, pencegahan, pemutusan rantai penularan, dan menghindari adanya penumpukan limbah Covid-19 (Kemenkes RI, 2020). Pembuangan limbah secara sembarangan oleh lembaga layanan kesehatan berkontribusi pada penyebaran penyakit terutama terjadi wabah pandemik. Pentingnya penanganan limbah medis rumah sakit selama terjadinya pandemik, maka beberapa peneliti memfokuskan studinya kepada pengelolaan limbah medis rumah sakit yang dikaji dari berbagai sudut pandang.

Beberapa penelitian menjelaskan definisi pandemik dan dampak negatif pada kesehatan yang diakibatkan oleh pandemik dan wabah penyakit (Qiu et al., 2017). Penelitian lain terkait tindakan pengaturan pengelolaan limbah medis dan prosedur pengelolaan limbah medis (Shareefdeen, 2012), tinjauan tentang pengelolaan limbah rumah sakit di negara-negara berkembang (Kementerian Kesehatan RI, 2020) dan limbah medis di Cina (Chinese Government, 2020). Secara tidak langsung penelitian tersebut berkaitan dengan penanganan pandemik dan pengelolaan limbahnya, namun belum berkaitan dengan Covid-19.

Penanganan pasien Covid-19 yang sangat meningkat membutuhkan perlengkapan medis yang lebih banyak. Hal ini akan mengakibatkan peningkatan limbah rumah sakit secara signifikan, sehingga membutuhkan peningkatan kapasitas pengelolaan limbahnya dari aspek kuantitas dan kualitasnya. Dengan demikian diharapkan tidak terjadi penularan kembali dari limbah medis B3 rumah sakit yang digunakan.

Tujuan dari penelitian ini adalah memberikan gambaran tentang manajemen pengelolaan air limbah, pengelolaan limbah padat domestik, dan pengelolaan limbah B3 medis berdasarkan pedoman Kemenkes RI tentang pengelolaan limbah RS rujukan yang menangani pasien Covid-19.

\section{METODE PENELITIAN}

Desain penelitian ini adalah desain penelitian kualitatif dengan pendekatan studi kasus yaitu mengenai manajemen limbah B3 medis padat rumah sakit rujukan di masa pandemik Covid-19 melalui wawancara mendalam, observasi langsung ke lokasi pengelolaan limbah dan dokumentasi yang dianalisis dengan model editing.

Penelitian ini dilaksanakan pada bulan April hingga Mei 2021 di Rumah Sakit Umum Daerah Kabupaten Polewali Mandar 
yang merupakan rumah sakit rujukan penderita Covid-19 di Sulawesi Barat.

Upaya untuk mendapatkan informasi yang lebih akurat berdasarkan tujuan penelitian maka peneliti menggunakan dua informan yaitu informan kunci dan informan biasa. Informan kunci adalah orang-orang yang sangat memahami permasalahan yang diteliti adapun yang dimaksud informan kunci dalam penelitian ini adalah Kepala Rumah Sakit, Penanggung Jawab Kesehatan Lingkungan, dan Petugas incenerator. Informan biasa adalah orang-orang yang dianggap mengetahui permasalahan yang diteliti. Adapun yang dimaksud informan biasa dalam penelitian ini adalah cleaning service, Kepala Ruangan Instalasi dan Bagian Perencanaan.

Instrumen dan teknik analisis data diperoleh di lapangan menggunakan teknik triangulasi bertujuan memperoleh data yang lebih jelas dan dapat dipercaya dengan menggunakan beberapa panduan penelitian yaitu pedoman wawancara, lembar observasi dan handphone sebagai dokumen sekaligus perekam suara.

\section{HASIL DAN PEMBAHASAN}

\section{Karakteristik Responden}

Responden yang terpilih menjadi sampel adalah orang-orang yang sangat memahami atau yang dianggap mengetahui permasalahan yang diteliti yang terdiri dari informan kunci dan informan biasa sebanyak 6 responden. Distribusi frekuensi karakteristik responden pada penelitian ini dapat dilihat pada tabel 1.

Tabel 1. Distribusi Responden berdasarkan Jenis Kelamin dan Tingkat Pendidikan

\begin{tabular}{ccc}
\hline $\begin{array}{c}\text { Karakteristik } \\
\text { Responden }\end{array}$ & Jumlah & $\begin{array}{c}\text { Persentanse } \\
(\%)\end{array}$ \\
\hline Jenis Kelamin & & \\
Laki-Laki & 4 & 66,7 \\
Perempuan & 2 & 33,3 \\
Tingkat Pendidikan & & \\
SMA/Sederajat & 2 & 33,3 \\
S1 & 2 & 33,3 \\
S2 & 1 & 16,7 \\
S2 & 1 & 16,7 \\
\hline
\end{tabular}

Berdasarkan tabel 1, diperoleh informasi bahwa sebagian besar responden dalam penelitian ini berjenis kelamin lakilaki dengan tingkat pendidikan didominasi oleh SMA/sederajat dan S1.

\section{Limbah Padat Domestik}

Limbah padat domestik adalah limbah yang berasal dari kegiatan kerumahtanggaan atau sampah sejenis, seperti sisa makanan, kardus, kertas, dan sebagainya baik organik maupun anorganik. Sedangkan limbah padat khusus meliputi masker sekali pakai, sarung tangan bekas, tisu/kain yang mengandung cairan/droplet hidung dan mulut (Kementerian Kesehatan RI, 2020).

Tabel 2. Manajemen Pengelolaan Limbah Padat Domestik di RSUD Polewali

\begin{tabular}{|c|c|c|}
\hline Manajemen & Informan & Interpretasi Hasil \\
\hline Perencanaan & $\begin{array}{l}\text { “...kalau perencanaan pengelolaan limbah } \\
\text { padat domestik Covid-19, limbah cair dan } \\
\text { limbah B3 itu sendiri, kami dari pihak Rumah } \\
\text { Sakit memang terlebih dahulu membuat } \\
\text { Perencanaan di awal tahun untuk mengatasi } \\
\text { limbah dimasa pandemi itu, secara } \\
\text { keseluruhan memang dari awal sebelum itu } \\
\text { setiap akir tahun kami sudah membuat } \\
\text { perencanaan na salah satu perencanaan yang } \\
\text { kita buat adalah untuk memisahkan ruang } \\
\text { perawatan Covid dengan ruang perawantan } \\
\text { pasien yang bukan pasien Covid-19 jadi } \\
\text { otomatis limbah Covid dan limbah bukan } \\
\text { Covid itu sudah terpisahkan memang dan } \\
\text { kami juga siapkan wadah yang khusus untuk } \\
\text { limbahnya...”(R1, R2, dan R5) }\end{array}$ & $\begin{array}{l}\text { Perencanaan } \\
\text { limbah terkait limbah padat } \\
\text { domestik covid-19, limbah cair } \\
\text { dan limbah B3 dilakukan pada } \\
\text { awal tahun. Salah satu } \\
\text { perencanaannya } \\
\text { memisahkan ruangan pasien } \\
\text { postif Covid-19 yang secara } \\
\text { otomatis limbah yang dihasilkan } \\
\text { juga terpisah dengan menggu- } \\
\text { nakan wadah khusus. }\end{array}$ \\
\hline
\end{tabular}




\begin{tabular}{ll}
\hline Pengorganisasian & “..iya kalau kita berbicara masalah \\
& petugaskan diRumah Sakit itu sumber daya \\
& manusianya sudah jelas ada dan itu sudah \\
& punya tugas masing-masing Setiap bidang to \\
& jadi kalau untuk limbah Covid-19 memang \\
& sudah ada kesehatan lingkungan yang \\
& menangani limbah Covid-19, tidak adaji \\
& petugas diluar yang kita ambil karna \\
& diRumah Sakit juga sudah memiliki bidang \\
& kesehatan lingkungan nanti kita memberikan \\
& pelatihan saja ...”(R1, R3, dan R5) \\
& "...kalau pelaksanaannya itu mulai dari \\
& persiapan alat seperti troli/kereta kemudian \\
& melakukan pengangkutan, pemilahan, \\
& pengumpulan limbah sampai ke proses \\
& pembakaran di incenerator adapun petugas \\
& juga itu menggunakan alat pelindung diri \\
& yang lengkap....” (R1, R3, dan R6) \\
& “...Iya tetap kami lakukan pengawasan ada \\
& yang dari DLHK dan dari Rumah Sakit, biar \\
& kita mengetahui apa-apa saja yang menjadi \\
& kendala atau hambatan dalam proses \\
& pemusnahan akhir...”(R1, R3, dan R5)
\end{tabular}

Sumber Daya Manusia yang dimiliki rumah sakit yang menangani limbah kasus Covid19 dilakukan oleh tim interal berasal dari bidang kesehatan lingkungan.

Pelaksanaan dalam menangani limbah padat domestik dimulai dari persiapan alat, pengangkutan, pemilahan, pengumpulan, dan pembakaran yang dilakukan oleh petugas dengan menggunakan APD lengkap.

Pengawasan dilakukan oleh $\mathrm{Ru}-$ mah Sakit dan Dinas Lingkungan Hidup dan Kehutanan Kabupaten Polewali Mandar.

\section{Air Limbah}

Air limbah kasus Covid-19 yang harus diolah adalah semua air buangan termasuk tinja, berasal dari kegiatan penanganan pasien Covid19 yang kemungkinan mengandung mikroorganisme khususnya virus corona, bahan kimia beracun, darah dan cairan tubuh lain, serta cairan yang digunakan palam kegiatan isolasi pasien meliputi cairan dari mulut dan/atau hidung atau air kimur pasien cucian alat kerja, alat makan dan minum pasien dan/atau cucian linen, yang berbahaya bagi kesehatan, bersumber dari kegiatan pasien isolasi covid-19, ruang perawatan, ruang pemeriksaan, ruang laboratorium, ruang pencucian alat dan linen (Kementerian Kesehatan RI, 2020).

Tabel 3. Manajemen Pengelolaan Air Limbah di RSUD Polewali

\begin{tabular}{lll}
\hline \multicolumn{1}{c}{ Manajemen } & \multicolumn{1}{c}{ Informan } & \multicolumn{1}{c}{ Interpretasi Hasil } \\
\hline Perencanaan & “...kalau perencanaan air limbah itu sudah & Perencanaan pengelolaan air \\
& ada memang mi perencanannya yang dibuat & limbah sudah dimiliki Rumah \\
& pihak Rumah Sakit ...” (R2, R3, R4, dan R6) & Sakit Umum Daerah Polewali \\
Pengorganisasian & “...iya ada kalau masalah petugas ada & Petugas pengelolaan air limbah \\
& memang dua orang yang menangani khusus & dilakukan oleh 2 orang yaitu \\
& pengelolaan air limbah yang ada di Rumah & bagian mesin dan bagian IPAL. \\
& Sakit kalau yang pertama ada di bagian & \\
& mesin dan kedua ada di bagian pembersih & \\
& IPAL...” (R1, R2, R3, dan R6) & \\
& “...e e e itu palaksanaan air limbah di Rumah & Air limbah yang dihasilkan dari \\
& Sakit kan itu semuanya lari nya ke IPAL & aktivitas pasien Covid-19 akan \\
& semua nanti di sana diproses mi ada dibilang & menuju ke IPAL. \\
& proses primary treatment, seconday treament, & \\
& tertiary treatmen, sludge treatment...” (R1 dan & \\
& R5) \\
& “...iya ada biasa saya cek kalau saya datang & Pengawasan dilakukan tiap hari \\
& di kantor...” (R2 dan R3) & oleh pimpinan RSUD Polewali \\
\hline
\end{tabular}




\section{Limbah B3 Medis Padat}

Limbah B3 Medis Padat adalah barang atau bahan sisa hasil kegiatan yang tidak digunakan kembali yang berpotensi terkontaminasi oleh zat yang bersifat infeksius atau kontak dengan pasien dan/atau petugas di Fasyankes yang menangani pasien Covid-19, meliputi: masker bekas, sarung tangan bekas, perban bekas, tisu bekas, plastic bekas minuman dan makanan, kertas bekas bahan makanan dan minuman, alat suntik bekas, set infus bekas, alat pelindung diri bekas, sisa makanan pasien, dan lain lain, berasal dari pelayanan kegiatan di UGD, ruang isolasi, ruang ICU, ruang perawatan, dan ruang pelayanan lainnya (Kementerian Kesehatan RI, 2020).

Tabel 4. Manajemen Pengelolaan Limbah B3 Medis Padat di RSUD Polewali

\begin{tabular}{|c|c|c|}
\hline Manajemen & Informan & Interpretasi Hasil \\
\hline Perencanaan & $\begin{array}{l}\text { “...kalau menyangkut limbah B3 dari awal } \\
\text { memang sudah saya bilang itu dari awal } \\
\text { tahun memang kita sudah buat } \\
\text { perencanaannya dari awal tahun kita sudah } \\
\text { buat memang dan masing-masing sudah } \\
\text { ada SOP nya...” (R1, R4, dan R5) }\end{array}$ & $\begin{array}{l}\text { Rencana pembuatan SOP pe- } \\
\text { ngolahan limbah B3 sudah di- } \\
\text { rencakan pembuatannya pada } \\
\text { awal tahun. }\end{array}$ \\
\hline Pengorganisasian & $\begin{array}{l}\text { “...iya kalau kita bicara petugaskan di } \\
\text { Rumah Sakit itu sumber daya manusianya } \\
\text { sudah jelas dan itu sudah punya tugas } \\
\text { masing-masing Setiap bidang to jadi kalau } \\
\text { untuk limbah Covid-19 memang sudah ada } \\
\text { kesehatan lingkungan yang menangani } \\
\text { limbah Covid-19, tidak adaji petugas diluar } \\
\text { yang kita ambil karna di Rumah Sakit juga } \\
\text { sudah bidang kesling nanti kita memberikan } \\
\text { pelatihan saja ...” (R1, R4, dan R5) }\end{array}$ & $\begin{array}{l}\text { Pengelolaan limbah B3 dila- } \\
\text { kukan oleh tim internal bagian } \\
\text { kesehatan lingkungan yang telah } \\
\text { diberikan pelatihan. }\end{array}$ \\
\hline Pelaksanaan & $\begin{array}{l}\text { “...kalau pelaksanaan limbah B3 padat } \\
\text { Covid kita siapkan wadah yang khusus } \\
\text { dilapisi dengan kantongan plastik warna } \\
\text { kuning dan mulai dari pengankutan dari } \\
\text { perawatan Covid itu alur nya juga berbeda } \\
\text { dengan limbah lain itu langung dibawah ke } \\
\text { incenerator..." (R1, R4, dan R5) }\end{array}$ & $\begin{array}{l}\text { Limbah padat B3 dimasukkan } \\
\text { dalam wadah yang dilapisi kan- } \\
\text { tong plastik kuning dan dihan- } \\
\text { curkan di incinerator. Pena- } \\
\text { nganan limbah B3 medis padat } \\
\text { ini memiliki jalur yang sesuai } \\
\text { dengan SOP }\end{array}$ \\
\hline Pengawasan & $\begin{array}{l}\text { "...iya itu saya lakukan tiap hari apa lagi } \\
\text { pada saat pembakaran limbah itu harus } \\
\text { betul-betul di perhatikan agar tidak ada } \\
\text { kesalahan tehknis pengaturan suhunya dan } \\
\text { sesuai SOP..." (R2, R3, dan } \mathrm{R} 4)\end{array}$ & $\begin{array}{l}\text { Pengawasan dilakukan pada } \\
\text { setiap alur penanganan limbah } \\
\text { B3 Medis padat }\end{array}$ \\
\hline
\end{tabular}

Penanganan pasien Covid-19 yang sangat meningkat membutuhkan perlengkapan medis yang lebih banyak. Hal ini akan mengakibatkan peningkatan limbah rumah sakit secara signifikan, sehingga membutuhkan juga peningkatan kapasitas pengelolaan limbahnya dari aspek kuantitas dan kualitasnya (Shareefdeen, 2012). Dengan demikian diharapkan tidak terjadi penularan kembali dari limbah medis B3 rumah sakit yang digunakan.
Manajemen pengelolaan limbah B3 medis padat di Rumah Sakit merupakan suatu sistem yang terstruktur dan terorganisir untuk pengelolaan agar tidak menimbulkan risiko ancaman kesehatan individu, kelompok maupun lingkungan sekitar jika tidak dilakukan pengelolaan dengan benar (Beracun et al., 2020).

Semua individu yang berada di rumah sakit berisiko untuk terpapar limbah Bahan Berbahaya dan Beracun (B3), tidak saja terhadap pasien namun juga individu yang 
bekerja di rumah sakit seperti tenaga medis, administrasi dan pendukung. Akibat pengelolaan yang kurang hati-hati, petugas yang berada di tempat perawatan kesehatan yang menghasilkan limbah B3 maupun yang berada di luar sumber ini namun bertugas untuk menangani limbah tersebut berisiko terpapar limbah B3 (Rudraswamy, 2014).

Manajemen Pengelolaan Limbah yang ada di Rumah Sakit Umum Daerah Polewali Mandar itu sudah berajalan dengan baik hal ini dibuktikan dengan adanya standar operasional prosedur (SOP) yang sudah ditetapkan oleh pihak Rumah Sakit yang akan dipedomani dalam Pengelolaan Limbah Medis Padat Domestik, Pengelolaan Air Limbah, dan Pengelolaan Limbah Bahan Berbahaya Dan Beracun (B3) yang ada di Rumah Sakit Umum Daerah Polewali Mandar, dalam hal ini pengelolaan limbah medis padat dan air limbah Rumah Sakit Umum Daerah Polewali Mandar sudah memiliki incenerator yang akan digunakan dalam pengelolaan/pembakaran limbah padat dan instalasi pengelolaan air limbah yaitu sebagai pengelolaan limbah cair yang dihasilkan oleh pasien yang ada di Rumah Sakit.

Penanganan limbah Covid-19 yang dihasilkan oleh pasien Covid yang ada di Rumah Sakit Rujukan Umum Daerah Polewali Mandar, dimulai dari tahap proses perencanaan, pengorganisasian, pelaksanaan dan pengawasan.

\section{a. Perencanaan}

Perencanaan adalah sebuah proses untuk merumuskan masalah-masalah kesehatan yang berkembang di masyarakat, menentukan kebutuhan dan sumber daya yang tersedia, menetapkan tujuan program yang paling pokok dan menyusun langkah- langkah praktis untuk mencapai tujuan yang telah ditetapkan (Qiu et al., 2017). Berdasarkan hasil wawancara kepada informan mengenai perencanaan pengelolaan air limbah Covid-19, pengelolaan limbah padat domestik Covid-19, dan pengelolaan Limbah Medis B3 Padat Covid-19 Rumah Sakit Umum Daerah Polewali Mandar (RSUD) dalam menangani kasus limbah Covid-19 ini, bahwa pihak Rumah Sakit telah membuat perencanaan pada awal tahun. Salah satu perencanaan yang dibuat adalah memisahkan ruangan perawatan pasien Covid-19 dan non Covid-19 jadi otomotis limbah yang dihasilkan pasien Covid dan non Covid itu sudah terpisah.

Rumah Sakit Umum Daerah (RSUD) Polewali dalam penanganan limbah telah memiliki SOP (Standar Operasional Prosedur) sebagai pedoman acuan bagi pihak-pihak yang terlibat dalam pengelolaan limbah mulai dari identifikasi, pemisahan, labeling, pengangkutan, penyimpanan hingga pembuangan/pemusnahan. Kepala Ruangan adalah Penanggung Jawab Kesling, Petugas Insenerator, dan cleaning service yang telah diberikan pelatihan. Petugas yang terlibat tersebut bekerja sesuai SOP, sehingga seseorang bekerja sesuai dengan bidang yang telah ditentukan dan penggunaan APD berdasarkan risiko kerjanya.

Dalam hal ini juga proses pengelolaan limbah medis di Rumah Sakit Umum Daerah yang dibutuhkan adalah biaya operasional serta ketersediaan biaya yang mencukupi. Hal ini sangat menunjang pelaksanaan kegiatan pengelolaan limbah medis di Rumah sakit Umum Daerah Polewali Mandar. Proses pengelolaan limbah medis terdiri dari tenaga pengelola, dana, dan sarana prasarana. Berdasarkan hasil wawancara ditemukan bahwa di RSUD sudah ada tenaga dengan kualifikasi kesehatan lingkungan sebagai tenaga pengawal pengolaan limbah medis. Berdasarkan hasil wawancara kepada informan dan survei diperoleh informasi bahwa anggaran pengelolaan limbah medis dan sarana prasarana di Rumah Sakit Umum Daerah Polewali Mandar itu diperoleh dari Badan Layanan Umum Daerah (BLUD).

Manajemen tenaga pengelola limbah medis rumah sakit sesuai dengan Kepmenkes No. 1204 tahun 2004 yaitu harus dikepalai oleh kepala IPAL dengan latar belakang pendidikan dengan kualifikasi sanitarian D3/S1 dan petugas pengelola limbah seperti cleaning service yang harus berlatar pendidikan minimal SMP dan ditambah pelatihan khusus dan pengawasan pengelolaan limbah rumah sakit dilakukan oleh tenaga sanitasi dengan ditambah latihan khusus. 


\section{b. Pengorganisasian}

Pengelolaan limbah di Rumah Sakit Umum Polewali mempunyai organisasi tersendiri dengan tingkat kompetensi dan akses organisasi baik, yang mana sudah ada bidang yang membawahi masalah sanitasi lingkungan RSUD Polewali (Instalasi Kesehatan Lingkungan). Sumber Daya Manusia yang dimiliki rumah sakit dalam menangani limbah kasus Covid-19 dilakukan oleh tim internal berasal dari bidang kesehatan lingkungan (Kehutanan, 2020).

Sumber daya manusia yang berada di Instalasi Kesehatan Lingkungan Rumah Sakit Umum Daerah Polewali mempunyai koordinasi yang baik dalam distribusi kerja. Hal ini dikarenakan pembagian kerja yang merata. Petugas kesehatan memiliki peran penting dalam pengelolaan lingkungan efek dari praktik mereka (Yu et al., 2020)

Sumber daya manusia yang bekerja di Instalasi Kesehatan Lingkungan yaitu petugas pengolahan limbah yang berhadapan langsung dengan limbah dan bertanggung jawab penuh atas limbah yang berasal dari rumah sakit maupun limbah yang berasal dari luar rumah sakit.

Patil mengemukakan program pelatihan wajib dilakukan untuk seluruh staf baru di rumah sakit untuk membiasakan mereka dengan prosedur operasi yang dipraktikkan di rumah sakit (Kementerian Lingkungan Hidup Dan Kehutanan, 2016).

Hasil survei pada personil, $85 \%$ termasuk manajer, staf pembersih, dan pekerja lingkungan, tidak dilatih untuk pengelolaan sampah di rumah sakit dan tidak memiliki penjelasan rinci tentang tugas mereka dalam hal penanganan limbah, 55\% dokter dan perawat tidak mengetahui protokol pengelolaan limbah rumah sakit dan menunjukkan pengetahuan yang cukup tentang potensi bahaya, dan $90 \%$ pekerja kota bertanggung jawab untuk transportasi limbah rumah sakit ke tempat pembuangan akhir dan tidak pernah waspada terhadap bahaya terkait dengan limbah rumah sakit (Guo, 2020).

Penelitian Nurmaladewi menyatakan petugas harus diberikan latihan yang tepat untuk memastikan sampah dikelola dengan benar untuk menjamin keselamatan karyawan dan orang lain (Yusuf, 2020).

\section{c. Pelaksanaan}

Kriteria sebagai pengelola limbah yang dihasilkan dari kasus terkonfirmasi positif Covid-19 tidak dijelaskan dalam SOP, tetapi lebih memuat pada persiapan alat dan pelaksanaan pengelolaan limbah. Selain itu SOP Pengelolaan Limbah baik itu limbah padat domestik, limbar cair, dan limbah B3 medis padat juga tidak menjelaskan secara jelas prosedur terkait langkah-langkah dalam pengelolaan limbah B3 medis padat sesuai dengan Pedoman Pengelolaan Limbah Rumah Sakit Rujukan yang menangani Pasien Covid-19 tahun 2020 (Kementerian Kesehatan RI, 2020).

Berdasarkan pelaksanaan pengelolaan air limbah Covid-19, pengelolaan limbah padat domestik Covid-19, dan pengelolaan limbah medis B3 padat Covid-19 tersebut maka dapat disimpulkan bahwa Rumah Sakit Umum Daerah Polewali Mandar (RSUD) dalam menangani kasus limbah Covid-19 sudah berjalan dengan baik. Hal ini dibuktikan dengan adanya Standar Operasional Prosedur (SOP) yang sudah dijalankan antara lain mulai dari pengangkutan, pemilahan, pemunahan dan pengiriman abu sisa hasil pembakaran.

Perlengkapan penunjang dalam upaya untuk menangani limbah B3 medis padat tertuang dalam Pedoman Pengelolaan Limbah Rumah Sakit Rujukan yang menangani Pasien Covid-19 menjelaskan dalam kegiatan pengelolaan sampah medis B3 fasilitas yang harus disediakan adalah alat transportasi khusus limbah dan petugas menggunakan APD. Limbah yang tidak langsung dilakukan pengolahan dapat disimpan dengan menggunakan freezer yang diatur suhunya di bawah $0^{\circ} \mathrm{C}$ di dalam TPS dan melakukan desinfeksi dengan desinfektan klorin 0,5\% pada limbah B3 secara menyeluruh sekurang-kurangnya sekali sehari (Kementerian Kesehatan RI, 2020).

Berdasarkan hasil penelitian dan observasi menunjukkan fasilitas yang disediakan Rumah Sakit Umum Polewali memiliki sarana peralatan dan APD yang sangat memadai untuk memperlancar kegiatan pengelolaan limbah B3 medis padat, tempat sampah yang dilapisi kantong plastik warna kuning dengan bersimbol "biohazard", troli, TPS, dan incenerator. 
Hasil penelitian ini sejalan dengan yang dilakukan di Rumah Sakit Umum (RSU) Bahteramas Provinsi Sulawesi Tenggara Tahun 2022 mengenai pengelolaan limbah medis di masa pandemi Covid-19, fasilitas penunjang yang disediakan adalah safety box, kantong plastik kuning dan hitam, troli dan TPS kantong palstik kuning dan hitam sebagai tempat limbah infeksius dan noninfeksius, troli sebagai pengangkut limbah menuju TPS (Hasanah, 2018).

Kasus terkonfirmasi positif Covid-19 yang semakin tinggi dapat meningkatkan bahaya dan risiko terpapar Corona Virus semakin tinggi pula. APD merupakan alat yang digunakan untuk menghindari atau mencegah paparan virus tersebut. Selama pandemi ini petugas pengelola limbah diwajibkan untuk menggunakan APD berdasarkan pedoman dari Kementerian Kesehatan demi mengurangi risiko kontaminasi virus maupun bakteri.

Pengelolaan limbah B3 medis padat harus dilakukan dengan efektif, benar, dan memenuhi persyaratan sanitasi. Karena sudah tidak digunakan lagi, tidak disukai dan harus dibuang, maka limbah tersebut harus dikelola dengan baik. Pengelolaan sampah merupakan kegiatan sistematis, komprehensif dan berkelanjutan yang meliputi pengurangan, pengolahan, dan pemusnahan sampah (Hasanah, 2018). Pengelolaan sampah medis perlu memilih sesuai sampah dan menyimpannya dalam kantong plastik yang berbeda sesuai dengan karakteristik atau jenis sampahnya. Sampah umum dimasukkan ke dalam plastik hitam, dan sampah infeksius dimasukkan ke dalam kantong plastik (Purwanti, 2015a).

Berdasarkan hasil wawancara dan observasi menunjukkan bahwa petugas telah melakukan langkah-langkah dalam menangani limbah yang dihasilkan selama pandemi covid-19 mulai dari identifikasi, pemisahan, labeling, pengangkutan, penyimpanan hingga pembuangan/ pemusnahan. Rumah Sakit Umum Daerah Polewali Mandar (RSUD) sudah memiliki izin penggunaan Incenerator sejak mulai dari Tahun 2017 sampai dengan 2021 baru dapat mengantongi izin Pengelolaan Limbah Medis Padat dari Kementerian Lingkungan Hidup dan Kehutanan Republik Indonesia (KLHK). Selain itu, Rumah Sakit Umum Daerah
Polewali Mandar juga melakukan kerja sama dengan pihak ketiga untuk mengambil hasil pembakaran atau sisa abu yang dihasilkan dari incinerator untuk diproses ke tempat pembuangan akhir yaitu PT. Bendi Nasha Niaga Indonesia Industri.

Hasil penelitian sejalan dengan Alvionita (2018) yang menunjukan bahwa di RSUD Dr. Soetomo, wadah limbah medis di ruangan dibagi menjadi tiga jenis, yaitu wadah limbah medis tajam, wadah limbah non medis, dan wadah limbah B3. Hal ini dilakukan dengan harapan sampah B3 sudah dipilah dari sumbernya berdasarkan jenis, kategori dan/atau karakteristik sampah B3 yang ada di ruangan tersebut (Purwanti, 2015). Sistem pengelolaan limbah padat pada RS. DR. H. Moch. Ansari Saleh Banjarmasin yaitu sistem pembakaran limbah padat dengan menggunakan incenerator sudah sesuai dengan peraturan. Hal ini dapat dilihat dari suhu yang digunakan $1.000{ }^{0} \mathrm{C}$ sampai dengan suhu $12.000{ }^{\circ} \mathrm{C}$ (Saleh, 2014).

\section{d. Pengawasan}

Pengawasan merupakan fungsi yang harus dilakukan setelah perencanaan, pengorganisasian, dan pelaksanaan dalam manajemen. Penelitian yang dilakukan Prasetiawan (2020) terkait permasalahan limbah medis Covid-19 menyatakan bahwa Indonesia masih bergantung pada insinerator sebagai teknologi pengolahan limbah. Pemerintah perlu menciptakan iklim investasi yang sehat bagi jasa pengolah dan pengangkutan limbah medis, serta perlu mengembangkan skema pembiayaan dalam mendukung pengelolaan limbah medis saat ini (Teddy, 2020). Dengan demikian Dinas Kesehatan, Dinas Lingkungan Hidup di berbagai lingkup baik pada Provinsi/Kabupaten/Kota harus tetap terus memantau pengelolaan limbah medis fasyankes terlebih pada masa pandemi Covid-19 (Tri Nurwahyuni et al., 2020).

Sehubungan dengan menajemen limbah medis di Rumah Sakit Umum Daerah Polewali Mandar, bahwa pengawasan atau controling dapat dianggap sebagai aktivitas untuk menemukan, mengoreksi penyimpanan penting dalam hasil yang ingin dicapai dari aktivitas yang telah dilaksanakan. Pengawasan dilakukan oleh Dinas Lingkungan Hidup dan Kehutanan Kabupaten Polewali Mandar. 
Pengolahan limbah B3 yang menggunakan alat insinerator, perlu memperhatikan izin pengolahan limbah B3 dahulu terkait spesifikasi dan informasi insinerator, temperatur ruang bakar utama dan kedua serta ketinggian cerobong, kemudian melakukan uji coba pembakaran (trial burn test) sebelum insinerator dioperasikan secara terus menerus atau kontinue. Pada saat pengoperasian perlu juga memperhatikan pengoperasiannya, pemantauan, hingga pelaporan kepada Kementerian Lingkungan Hidup dan Kehutanan (KLHK) per semester (6 bulan sekali) (Kementerian Lingkungan Hidup Dan Kehutanan, 2016).

\section{KESIMPULAN DAN SARAN}

Manajemen Pengelolaan Limbah Padat Domestik, Limbah Cair, dan Limbah B3 Medis Padat Rumah Sakit Umum Daerah Polewali sudah memiliki SOP dengan merujuk pada Pedoman Pengelolaan Limbah rumah Sakit Rujukan, Rumah Sakit Darurat dan Puskesmas yang menangani Pasien Covid-19 tahun 2020 terkait dengan proses pemilahan, pewadahan, pengumpulan, pengangkutan dan pemusnahan, serta pembuangan akhir Rumah Sakit Umum Polewali melakukan kerja sama dengan pihak ketiga yaitu PT. Bendi Nasha Niaga Indonesia Industri. Perlu dilakukan penelitian lanjutan terkait uji toksisitas terkait limbah padat domestik, limbah cair, dan limbah B3 medis padat dimasa pandemi covid-19 sebelum dibuang ke lingkungan.

\section{REFERENSI}

Astuti, L. T. M. (2020) Webinar Covid-19 Persi: Satu Pasien Di Rs Rujukan Dan Darurat Hasilkan 14,3 Kg Limbah Medis Per Hari, Persi.

Beracun, D. A. N. Et Al. (2020) 'Prediction Of Medical Hazardous Waste Generation From Covid-19 Patient Handling Hospitals Perkiraan Timbulan Limbah Medis Bahan Berbahaya', 15(1), Pp. 12-18.

Chinese Government (2020) Guide On Management And Technical On Emergency Treatment And Disposal Of Medical Waste Caused By Covid19 (Trial). Available At: Http://Www.Mee.Gov.Cn/Ywdt/Xwf
b/202001/T20200129_761043.Shtml.

Dinas Kesehtan Sulawesi Barat (2020) Data Pantauan Covid-19 Sulawesi Barat Progra, Surveilans, Dinkes Sul-Bar.

Direktor Pelayanan Kesehatan Primer (2020) Petunjuk Teknis Pelayanan Puskesmas Pada Mada Pandemi Covid-19. Jakarta: Kemeterian Kesehatan Ri.

Guo, Y.-R. (2020) 'The Origin, Transmission And Clinical Therapies On Coronavirus Disease 2019 (Covid19) Outbreak - An Update On The Status', Military Medical Research, 41(22), Pp. 2124-2125. Doi: 10.1093/Eurheartj/Ehaa396.

Hasanah, L. (2018) 'Gambaran Pengelolaan Limbah Medis Padat Pada Pos Kesehatan Desa (Poskesdes) Di Kecamatan Bluto', Gorontalo Journal Of Public Health, 1(2), P. 65. Doi: 10.32662/Gjph.V1i2.333.

Kehutanan, K. L. H. Dan (2020) Surat Edaran Pengelolaan Limbah Infeksius (Limbah B3) Dan Sampah Rumah Tangga Dari Penanganan Corona Virus Disease (Covid-19).

Kemenkes Ri (2020) Persyarakatan Kesehatan Lingkungan Rumah Sakit. Jakarta.

Kementerian Kesehatan Ri (2020) Pedoman Pengelolaan Air Limbah Pengelolaan Limbah Padat Domestik Pengelolaan Limbah B3 Medis Padat, Kementerian Kesehatan Ri. Jakarta.

Kementerian Lingkungan Hidup Dan Kehutanan (2016) Peraturan Menteri Lingkungan Hidup Dan Kehutanan Republik Indonesia Tentang Tata Cara Dan Persyaratan Teknis Pengelolaan Limbah Bahan Berbahaya Dan Beracun Dari Fasilitas Pelayanan Kesehatan.

Kwan, M. (2020) Meninjau Aturan Dan Pengelolaan Limbah Infeksius Dan Sampah Rumah Tangga Era Covid19, Mongabay, Situs Berita Lingkungan.

Purwanti, A. A. (2015) 'Pengelolaan Limbah Padat Bahan Berbahaya Dan Beracun (B3) Rumah Sakit Di Rsud Dr.Soetomo Surabaya', Jurnal Kesehatan Lingkuangan, 10(3), Pp. 291-298. 
Qiu, W. Et Al. (2017) 'The Pandemic And Its Impacts', Health, Culture And Society, 9(10), Pp. 1-11. Doi: 10.5195/Hcs.2017.221.

Rudraswamy, S. (2014) 'Hazards And Public Health Impacts Of Hospital Waste', Indian Journal Of Applied Research, 4(6), Pp. 384-386. Doi: 10.15373/2249555x/June2014/120.

Saleh, M. A. (2014) 'Sistem Pengelolaan Limbah Padat Pada Rs. Management Systems Of Solid Waste In The Hospital Dr', An-Nadaa Artikel Ii, 1(1), Pp. 5-9.

Satuan Tugas Penangan Covid-19 (2020) Data Sebaran Covid-19, Komite Penanganan Covid-19 Dan Pemulihan Ekonomi.

Shareefdeen, Z. M. (2012) 'Medical Waste Management And Control', Journal Of Environmental Protection, 03(12), Pp. 1625-1628. Doi: 10.4236/Jep.2012.312179.
Teddy, P. (2020) 'Permasalahan Limbah Medis Covid-19 Di Indonesia', Info Singkat, 12(9), Pp. 13-18.

Tri Nurwahyuni, N. Et Al. (2020) 'Pengolahan Limbah Medis Covid-19 Pada Rumah Sakit', Jurnal Kesehatan Lingkungan, 10(2), Pp. 52-59. Doi: 10.47718/Jkl.V10i2.1162.

World Health Organization (2021) Weekly Operational Update On Covid-19, World Health Organization (Who).

Yu, H. Et Al. (2020) 'Reverse Logistics Network Design For Effective Management Of Medical Waste In Epidemic Outbreak: Insights From The Coronavirus Disease 2019 (Covid-19) In Wuhan', Ssrn Electronic Journal, 17. Doi: 10.2139/Ssrn.3538063.

Yusuf, S. (2020) 'Pengelolaan Limbah Medis Padat Di Masa Pandemi Covid-19 Di Rumah Sakit Umum (Rsu) Bahteramas Provinsi Sulawesi Tenggara 2020', Jurnal Ilmiah Ilmu Kesehatan, 5(2), Pp. 64-71. 